Vol. 41: 1-20, 2013

\title{
Post-cyclone livelihood status and strategies in coastal Bangladesh
}

\author{
Shitangsu Kumar Paul \\ Department of Geography and Environmental Studies, \\ University of Rajshahi, Rajshahi 6205, Bangladesh. \\ E-mail:shitangsuk@yahoo.com
}

\begin{abstract}
The objective of this paper is to assess post-cyclone livelihood capitals status, identify major livelihood groups, adversity and crisis, and present the livelihood strategies of coastal households. Based on a questionnaire survey at household level, a total 331 out of 792 households are selected through simple random sampling from three purposively selected villages in the central coast of Bangladesh. Both descriptive and inferential statistics are used to analyse data. The present study identifies wage labour, fisher and farmer as major livelihood groups. Among the three villages, Island reveals less livelihood capitals than inland and shoreline. Although natural capital of Island is relatively higher, however, scarcity of other capitals hinders proper utilization of the potentials of such capital. Social capital of Island is significantly lower than other two villages, which unveils relatively lesser social coherence of Islanders, and which is most important to survive in post-cyclone situation. Likewise, among the livelihood groups, wage labourer owes less livelihood capitals than farmer and fishermen. Majority of the households irrespective of their village locations identifies recurrent cyclones and induced storm surges as major adversities which significantly destroys their livelihoods. Therefore, households in study villages diversify income sources wherever possible and most importantly while face the crisis. In general, livelihoods of Islanders and Shoreline villagers, wage labourer and fish fry collectors are most vulnerable to any cyclone events. Hence, the present study advocates for identifying vulnerable locations and livelihood groups, and livelihood capitals building for such groups and promoting coordinated disaster risk reduction programs to mitigate cyclone impacts and providing assistance for rebuilding post-cyclone livelihoods.
\end{abstract}

Keywords: Cyclone, livelihood capitals, livelihood strategies, adversity and crisis, Bangladesh.

\section{Introduction}

The geographic location and the unique natural setting of Bangladesh in the South Asian subcontinent together with it's unusual characteristics of tropical monsoon climate are greatly responsible for all catastrophic natural disasters (Elahi, 1991; Haque, 1995; Paul, 2009; Paul \& Routray, 2010). Cyclone, flood, drought, tornados, nor-wester, riverbank erosion, coastal erosion and so on occur in the country round the year (Ali, 1999; Choudhury et al., 2006). Among these, cyclone and flood is most frequent and considered to be the major hazards of the country. In terms of the likelihood of occurrence, at least one major tropical cyclone strikes the country in each year (Mooley, 1980; Haque, 1997) together with powerful storm surges that assert hundreds of thousands of lives and make Bangladesh coast more unsafe than any other regions of the world (Murty \& Neralla, 1992). Besides, 
the basic physical and meteorological conditions necessary to generate tropical cyclone exists in the Bay of Bengal and Bangladesh coast. These pre-requisite conditions are: the re-curvature phenomenons of tropical cyclone in the Bay of Bengal, shallow continental shelf, funnel shape at the head of the Bay of Bengal, sea-level Orography of the Bangladesh coast, and high density of population (Murty \& El-Sabh, 1992). Therefore, this unique setting modifies and regulates the climatic conditions of the country and makes the country more vulnerable to natural disasters such as cyclones accompanied by storm surge and coastal flooding etc. (Ali, 1996, 1999; Paul \& Routray, 2010b).

Several disastrous cyclones hit Bangladesh in 1822, 1876, 1961, 1965, 1970, 1991 and 2007 (Blaikie et al., 1994; Dube et al., 1997; GoB, 2008). Among these in 1970, 1991 and 2007, about 500,000, 138,000 and 3,406 people died respectively (Ali, 1980; Choudhury, 1989; Haider et al., 1991; Chowdhury, 1995; GoB, 2008). On the night of November 15, 2007, Cyclone Sidr, a Category 4 storm, made landfall across the south-western coast, and travelled through the heart of the country from the southwest to the northeast (Figure 1). With winds recorded as strong as 248 kilometres per hour, it triggered storm surges as high as 7.5 meter in some coastal districts. Due to cyclone Sidr over 55,000 people sustained physical injuries (GoB 2008a), an estimated 1.87 million livestock and poultry perished, and crops on 2.51 million acres suffered complete or partial damage. In addition, the cyclone washed away private food stockpiles and storages and destroyed 1.4 million fruit trees. The Joint Damage Loss and Needs Assessment Mission, led by the World Bank, estimated the total cost of the damage caused by Cyclone Sidr is $\$ 1.7$ billion, a figure which represents about three percent of the annual gross national product of Bangladesh (GoB, 2008a). Cyclone Sidr severely affected over 7.46 million people's livelihood (GoB, 2008a). According to a rapid emergency assessment completed by UN officials, 2.6 million people were found to be in need of immediate food assistance across the affected areas (UN, 2007). Besides, increased salinity caused by storm surges during the cyclone and soil deposition has further hampered agricultural productivity. The officials highlighted the largescale loss of standing crops, family food stocks and livestock. These losses were compounded by the virtual collapse of already meagre wage-earning opportunities together with price hike of essential food commodities in the aftermath of cyclone Sidr affected areas makes the livelihoods of cyclone victims insecure (GoB, 2008b).

Cyclone is always followed by storm surges and torrential rainfalls, therefore coastal population of Bangladesh have to face three types of disaster simultaneously that make their livelihood insecure. Hence, it is important to explore the impacts of cyclone and storm surge on coastal inhabitants' livelihoods, and explore the livelihood strategies considering access to resources. Broadly the concepts of 'asset vulnerability framework' (Moser et al., 1994); household's 'access to resources' (Blaikie et al., 1994); Sustainable Livelihood Framework (DFID, 1999) and Household Livelihood Security Model (Sanderson, 2000) are reviewed and conceptualized; and more emphasis is given on sustainable livelihood framework and household livelihood security model to outline how different resources (assets/capitals) mediate livelihood strategies in disaster 
situation and also in usual time to secure livelihood. The basic livelihood framework in Carney (1998) stresses the need to maintain 'outcome focus' thinking about how development activity impacts people's livelihoods. This framework has mainly been used for basic needs program by CARE International, for poverty elimination by the UK Department for International Development (DFID), and for designing many fisheries, livestock, forestry, rural development, and poverty alleviation investment projects and programs, as well as for monitoring stakeholder participation by the Food and Agricultural Organization (FAO) of the United Nations. However, it has not been used in disaster management field, and various livelihood variables related to disaster and livelihood were not yet been specifically defined nor their measurement methods developed (Shivakoti \& Shrestha, 2005). Apart from the livelihoods, in the present trends of disaster research, various aspects of Cyclone Sidr have received the attention of hazard researchers such as cyclone early warning, non-response and evacuation behaviour (Paul \& Dutt, 2010; Paul \& Routray, 2012; Paul, 2014); causes of reduced deaths, injuries and illness pattern (Paul, 2009; Paul 2010; Paul et al., 2011); coping response and adjustment strategies to cyclone and other disasters (Mallick et al., 2009; Paul \& Routray, 2010a; Paul \& Routray, 2010b); impacts of cyclone on coastal physical infrastructures and social conditions (Islam et al., 2011; Paul, 2012), post-Sidr nutritional status of women and children (Paul, 2010; Paul et al., 2012), household food security status of marginal farmers and so on (Uddin, 2012). However, post-cyclone livelihood capital status and strategies among residents of the affected areas has not been the focus of any study. To address this research gap, this paper will assess the livelihood capital status; identify livelihood groups, major livelihood adversity and crisis, and livelihood strategies of coastal households in the post-Sidr period. Findings of this study would provide useful guidelines for further interventions and targeting the marginal livelihood groups and locations with more effective post-cyclone livelihood rehabilitation related programs.

\section{Study area, materials and methods}

Selection of study villages

Three villages from two of the four most severely Sidr-affected districts in Bangladesh were selected for this study (Figure 1). The selected villages are: Angulkata of the Amtoli thana; Tatulbaria of the Taltoli thana, and Charkashem of the Rangabali thana. The first two villages are located in the Barguna district, and the last one in the Patuakhali district. Charkashem is an offshore island; Tatulbaria is located on the shoreline of the Bay of Bengal; and Angulkata is approximately $30 \mathrm{~km}$. away from the sea, on the bank of the river Paira. All three villages experienced storm surges ranging from 3.0 meters to 7.0 meters. Angulkata and Tatulbaria are surrounded by polder. On the contrary, the southern part of Charkashem is covered by mangrove trees planted under a coastal afforestation program. For the purpose of making locational distinctions, Angulkata is termed as inland village, Tatulbaria as shoreline village, and Charkashem as island village. Comparative aspects of livelihoods and vulnerability to cyclone in three villages are presented in Table 1. 


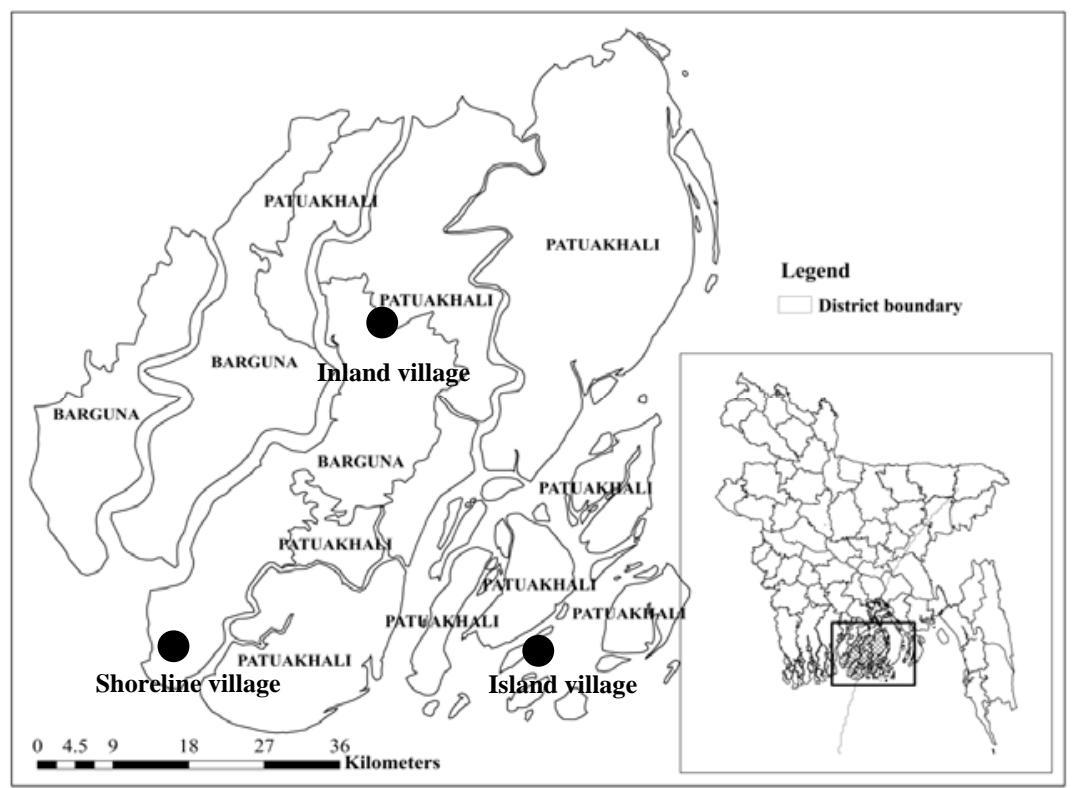

Figure 1. Location of study villages.

Table 1. Comparative aspects of livelihoods and vulnerability in three villages.

\begin{tabular}{|l|l|l|l|}
\hline \multirow{2}{*}{ Variables } & \multicolumn{1}{c|}{ Inland } & \multicolumn{1}{c|}{ Shoreline } & \multicolumn{1}{c|}{ Island } \\
\cline { 2 - 4 } $\begin{array}{l}\text { Primary } \\
\text { livelihood } \\
\text { activities }\end{array}$ & $\begin{array}{l}\text { Agriculture and } \\
\text { allied }\end{array}$ & Fishing and allied & Fishing and allied \\
\hline $\begin{array}{l}\text { Secondary } \\
\text { livelihood } \\
\text { activities }\end{array}$ & Fishing and allied & $\begin{array}{l}\text { Agriculture and } \\
\text { allied }\end{array}$ & Agriculture and allied \\
\hline $\begin{array}{l}\text { Vulnerability of } \\
\text { livelihoods to } \\
\text { cyclone and } \\
\text { storm surge }\end{array}$ & $\begin{array}{l}\text { Moderate } \\
\text { vulnerability to } \\
\text { cyclone with 2-3 } \\
\text { meter of associated } \\
\text { storm surge }\end{array}$ & $\begin{array}{l}\text { Very high } \\
\text { vulnerability to } \\
\text { cyclone with 3-4 } \\
\text { meter of associated } \\
\text { storm surge }\end{array}$ & $\begin{array}{l}\text { Very high } \\
\text { vulnerability to } \\
\text { cyclone with more } \\
\text { than 4 meter of } \\
\text { associated storm surge }\end{array}$ \\
\hline $\begin{array}{l}\text { Level of risk of } \\
\text { livelihoods }\end{array}$ & Moderate & Very high & Very high \\
\hline
\end{tabular}

Source: Household Survey and Focus Group Discussion, 2009. (Note: Level of vulnerability and risk is assessed based on five point Likert scale)

Of the 792 households in three selected villages, a sample size of 331 was determined using an assumed 95\% confidence level for the household questionnaire survey (Yamane, 1967). The number of samples selected from Angulkata and Tatulbaria was proportional to their total household size. Due to its small size, all 47 households in Charkashem were selected for this study. The individual household was the study unit and the households were selected from 
Angulkata and Tatulbaria using a simple random sampling procedure. Cyclone and livelihood related information was collected from the head of the selected households and local leaders through informal dialogue. One focus group discussion (FGD) was also conducted in each study village. Informal discussions and FGDs were carried out to gain additional insights regarding post-cyclone livelihood strategies at household level. Both descriptive and inferential statistics are used to analyse data. In addition, a five point Likert scale is used to assess level of risk, vulnerability and livelihood capitals of respondents. Besides, application of the analysis of variation (ANOVA) is also used to identify statistically significant difference among the villages and livelihood groups in terms of livelihood capitals.

\section{Measuring livelihood capitals}

Following DFID and CARE International's livelihood framework an analytical model is developed by identifying the relevant indicators of five livelihood capitals, and indicators are defined considering the coastal livelihoods of Bangladesh (Carney, 1998; Carney et al., 1999). A five point Likert scale is used to measure five types of livelihood capitals considering the discrete values of 0.00 , $0.25,0.50,0.75$ and 1 .

\section{Human capital index (HCI)}

Indicators considered to measure human capital index value are household head's education level, ability to work in adverse condition, having disaster related training, level of experience gained from training, solving own problems, representative of group, exposing idea in group meeting, helping other to solve problem, motivating others for community activities, facilitating community and GO-NGO initiatives, and solving conflict within the community. Below formula is used to calculate human capital index value.

$$
\mathrm{HCI}=\left(\sum \mathrm{HCI}_{1} / \mathrm{N}+\sum \mathrm{HCI}_{2} / \mathrm{N} \ldots \ldots \sum \mathrm{HCI}_{11} / \mathrm{N}\right) / 11
$$

Where, $\mathrm{HCI}=$ Human Capital Index, $\mathrm{HCI}_{1}, \mathrm{HCI}_{2} \ldots . .=$ Human Capital Indicators, $\mathrm{N}=$ Total sampled respondents.

Natural capital index (NCI)

Natural capital index (NCI) value is calculated by adding the average of nine selected natural capital indicators (i.e. access to open water bodies, forests, grazing lands, and khas and/or char lands, soil fertility status, trend of soil fertility change in past ten years, sufficiency of water for irrigation, soil salinity status, and frequency of tidal surge events) and dividing the total by 9 .

$\mathrm{NCI}=\left(\sum \mathrm{NCI}_{1} / \mathrm{N}+\sum \mathrm{NCI}_{2} / \mathrm{N} \ldots \ldots \sum \mathrm{NCI}_{9} / \mathrm{N}\right) / 9$

Where, $\mathrm{NCI}=$ Natural Capital Index, $\mathrm{NCI}_{1}, \mathrm{NCI}_{2} \ldots . .=$ Natural Capital Indicators, $\mathrm{N}=$ Total sampled Respondents

Financial capital index (FCI)

Indicators considered to measure financial capital index are available financial deposits and monetary values of liquid assets of each households such as reserve of money in the form of cash, deposits in banks, cooperatives and groups, remittance and pension, and liquid assets from livestock, poultry, jewellery, 
furniture, storage of food and cash crops, trees and other assets which can provide liquid money. After converting all form of such assets into monetary values for each household, is divided by the aggregate highest available financial deposit and monetary value among the study villages to get financial capital index.

$\mathrm{FCI}=\mathrm{Av} / \mathrm{Av}_{\mathrm{h}}$

Where, FCI $=$ Financial Capital Index, $A v=$ Available financial deposit and monetary value of liquid assets of each household, $A v_{h}=$ Highest available financial deposit and monetary value among the study villages

\section{Physical capital index (PCI)}

Physical Capital Index is measured considering the quality of road to reach in market, accessibility to road, access to cyclone shelters, access to agricultural and fishing accessories such as tractor, harvester, boat, net, and means of transportation such as rickshaw, van, motorbike, and bicycle.

$\mathrm{PCI}=\left(\sum \mathrm{PCI}_{1} / \mathrm{N}+\sum \mathrm{PCI}_{2} / \mathrm{N} \ldots \ldots \mathrm{PCI}_{9} / \mathrm{N}\right) / 9$

Where, $\mathrm{PCI}=$ Physical Capital Index, $\mathrm{PCI}_{1}, \mathrm{PCI}_{2} \ldots . .=$ Physical Capital Indicators, $\mathrm{N}=$ Total sampled respondents.

\section{Social capital index (SCI)}

Three broad groups such as access to mass communication and individual communication, participation and connection, and memberships in the groups are considered to measure social capital index values.

Mass communication and individual communication index

Indicators for mass communication and individual communication include household head's access to radio, television, mobile phone, newspaper, printed materials, disaster mitigation, agriculture extension, fishery, health and family planning personals and Union Parishad, NGOs and CBOs.

$\mathrm{MICI}=\left(\sum \mathrm{MICI}_{1} / \mathrm{N}+\sum \mathrm{MICI}_{2} / \mathrm{N} \ldots \ldots .2 \mathrm{MICI}_{11} / \mathrm{N}\right) / 11$

Where, $\mathrm{MICI}=$ Mass Communication and Individual Communication Index, $\mathrm{MICI}_{1}, \mathrm{MICI}_{2} \ldots \mathrm{MICI}_{11}=$ Mass Communication and Individual Communication Indicators, $\mathrm{N}=$ Total sampled respondents.

\section{Participation and connection index}

Participation and connection indicators include participation on community based awareness campaign, disaster mitigation activities, connection with NGOs for disaster mitigation, relationship with others in the community, and assisting others in the community during crisis.

$\mathrm{PACI}=\left(\sum \mathrm{PACI}_{1} / \mathrm{N}+\sum \mathrm{PACI}_{2} / \mathrm{N} \ldots \ldots \mathrm{PACI}_{5} / \mathrm{N}\right) / 5$

Where, PACI $=$ Participation and Connection Index, $\mathrm{PACI}_{1}, \mathrm{PACI}_{2} \ldots . \mathrm{PACI}_{5}=$ Participation and Connection Indicators, $\mathrm{N}=$ Total sampled respondents.

\section{Membership index}

Membership is measured through involvement in voluntary, religious, microcredit, cooperative groups and Union Parishad. 
$\mathrm{MGI}=\left(\sum \mathrm{MGI}_{1} / \mathrm{N}+\sum \mathrm{MGI}_{2} / \mathrm{N} \ldots \ldots \mathrm{MGI}_{5} / \mathrm{N}\right) / 5$

Where, MGI $=$ Membership in Groups Index, $\mathrm{MGI}_{1}, \mathrm{MGI}_{2} \ldots \mathrm{MGI}_{5}=$ Memberships in Groups Indicators, $\mathrm{N}=$ Total sampled Respondents

Finally, overall social capital index (SCI) is calculated based on the average of mass communication and individual communication, participation and connection, and memberships.

\section{Results and discussion}

Performance of livelihood capitals and asset pentagon

The present study finds that overall human capital is higher in Shoreline village with a value of 0.41 out of 1 than Inland (0.34) and Island (0.31) villages respectively. Application of the analysis of variation (ANOVA) indicates that the selected villages significantly differ in terms of human capital. Respondents of Shoreline village have better accomplishment of human capital than other two. On the contrary, Island village $(0.59)$ has higher natural capital than Shoreline $(0.57)$ and Inland (0.50). It is due to the higher access of Island villagers to open access common natural resources such as sea, river, grazing lands and khas lands. Higher access to such resources had attracted many migrants to settle in that village, though this is most vulnerable location to cyclone among the three villages. Similarly, Shoreline village also enjoys more natural capital than Inland. As Shoreline village is located in the seashore of the Bay of Bengal, hence villagers have higher access to deep-sea fishing. On the other hand, inland village is agrobased and limited common resources are available. Therefore, natural capital index reveals relatively lower value. 'Duncan test', which is a post-hoc test of multiple comparisons (Permanasari et al., 2010) confirms that there is no significant difference among the villages in terms of financial capital. However, though statistically significant difference does not exists but financial capital index value is comparatively higher in Shoreline (0.055) than Inland (0.049) and Island (0.031) villages (Table 2). Among the villages, Island accounted for lower financial capital which reveals in general poor economic condition of respondents. Physical capital index reveals higher value for Shoreline (0.51) than Inland (0.42) and Island (0.28) villages. Higher physical capital index value in Shoreline reveals that respondents had higher access and ownership of physical assets such as fishing and agricultural accessories. Fishermen in Shoreline village usually catch fish in deep-sea thus requires huge amount of investment for mechanized boats and nets. On the other hand, large number of respondents in Island village are also fishermen, but usually unable to invest more money for boat and nets due to poor economic condition. Agricultural accessories are not as expensive as fishing accessories; and number of farmer is higher than fisher, and fishermen are engaged in subsistence level fishing, hence Inland village shows less physical capital index value. Social capital index value shows better situation in Shoreline $(0.32)$ followed by Inland $(0.29)$ and Island (0.21) villages (Table 2). Higher performance of social capital index values in Inland village indicates better social coherence among the inland coastal communities. On the other hand, majority of the respondents in Island are the immigrants from different inland locations, therefore social bonding is not as tight as Inland locations. Likewise, institutional activities are also comparatively less in 
the Island village due to poor communication network and remoteness. On the other hand, due to the proximity to the nearby thana headquarters respondents in Inland and Shoreline villages enjoys more services from government and nongovernment organizations. However, such locational advantage provide benefit to the villagers of Shoreline and Inland for example access to information, and link with GO and NGOs. Such facilities in fact, help inland villagers for relatively better disaster preparedness, rescue, relief and rehabilitation.

Table 2. Livelihood assets index by village and livelihood groups.

\begin{tabular}{|l|c|c|c|l|}
\hline \multirow{2}{*}{$\begin{array}{c}\text { Livelihood } \\
\text { capitals }\end{array}$} & \multicolumn{5}{|c|}{ Study villages } \\
\cline { 2 - 5 } & Inland & Shoreline & Island & \multicolumn{1}{c|}{ ANOVA } \\
\hline Human & 0.34 & 0.41 & 0.31 & $\mathrm{~F}=11.87^{* *}$ \\
\hline Natural & 0.50 & 0.57 & 0.59 & $\mathrm{~F}=39.64 * *$ \\
\hline Financial & 0.049 & 0.055 & 0.031 & $\mathrm{~F}=2.255$ \\
\hline Physical & 0.42 & 0.51 & 0.28 & $\mathrm{~F}=54.71^{* *}$ \\
\hline Social & 0.29 & 0.32 & 0.21 & $\mathrm{~F}=17.69^{* *}$ \\
\hline Livelihood & \multicolumn{5}{|c|}{ Livelihood groups } \\
\cline { 2 - 6 } Capitals & Farmer & Fisher & Wage labourer & $\mathrm{ANOVA}$ \\
\hline Human & 0.39 & 0.36 & 0.30 & $\mathrm{~F}=12.103^{* *}$ \\
\hline Natural & 0.55 & 0.60 & 0.53 & $\mathrm{~F}=21.153^{* *}$ \\
\hline Financial & 0.08 & 0.04 & 0.03 & $\mathrm{~F}=14.615^{* *}$ \\
\hline Physical & 0.46 & 0.48 & 0.33 & $\mathrm{~F}=51.106^{* *}$ \\
\hline Social & 0.28 & 0.27 & 0.24 & $\mathrm{~F}=9.358^{* *}$ \\
\hline
\end{tabular}

$\mathrm{p}<0.05,{ }^{* *} \mathrm{p}<0.01$, Source: Household Survey, 2009.

Likewise, application of the analysis of variation (ANOVA) indicates that access to livelihood assets significantly varies among three livelihood groups (Table 2). Based on 'Duncan test' it reveals that accesses to livelihood capitals are significantly higher for farmer and fisher than wage labourer. This reveals relatively weaker asset portfolio of wage labourer than farmer and fisher. Between farmer and fisher; human, financial and social capital index value is higher for farmer, while natural and physical capital index value is higher for fishermen. This indicates relatively better situation of farmer than fishermen. Higher human capital unveils better physical ability, skill and knowledge of farmer than fisher. Similarly, having higher financial capital of fishermen reveals higher ability of converting liquid assets and savings to gain other capitals. Higher social capital of farmer demonstrate relatively better participation and connection status and social coherence of this group with other various community groups. Social coherence, a part of social capital helps farmer to cope with post-cyclone crisis such as providing food to neighbours immediately after cyclone while institutional assistances are not available, and helping each other to reconstruct destroyed houses. On the other hand, higher natural capital of fishermen reveals higher access of fishing communities to common resources such as sea and rivers. Fishing accessories require higher investment than agriculture accessories. Therefore, physical capital for fisher groups is higher than farmer. 
Radar diagrams are plotted based on the calculated scores of five livelihood capital indices to present in livelihood asset pentagon (Figures 2 and 3). The shape of pentagon represents the variations in villagers' and livelihood groups' access to five livelihood capitals. The centre point of the pentagon represents the zero value in terms of access to assets. While, deviations from the centre point of pentagon to the outer sides represents higher values of livelihood capitals. Figures 2 and 3 present the livelihood asset pentagon to depict the overall access to five livelihood capitals by villagers and livelihood groups.

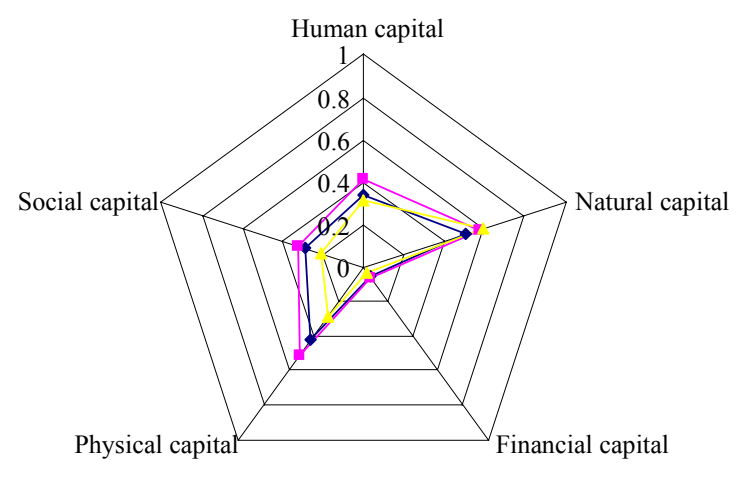

$\bullet$ Inland village — $\_$Shoreline village $\_$Island village

Figure 2. Livelihood asset pentagon by village.

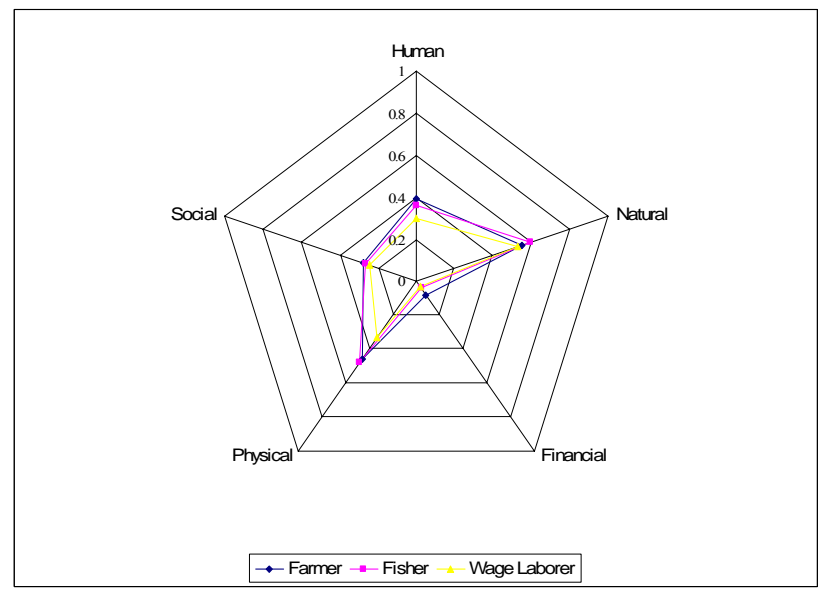

Figure 3. Livelihood asset pentagon by livelihood groups. 
Major livelihood groups and strategies

Together with other factors land is considered as one of the important determining factors of socio-economic class variation in rural Bangladesh. People's occupations coupled with associations of production often portray livelihood groups; for instance fishers, day labour or wage labour are classified as distinct social class with low status; whereas small farmer and large land owners is elite rural people with an image of patron (PDO-ICZMP, 2004a). Agricultural labour is the largest livelihood group in terms of number in rural Bangladesh. Generally, one in every three households is depended on agriculture. Small farmers are the transitional groups between landless and large landowners though they are very close to landless. Fishermen are the single largest groups among the nonagricultural occupations. However, livelihoods in the coastal Bangladesh are broadly clustered into two groups such as natural resource based (agriculture, fishing, aquaculture, extraction of forest resources) and human resource based (boat building, net making, fish processing, trading). There are over seven million households in coastal zone, out of which agricultural labourer, small farmer, fisher and urban poor cover 71 percent of total households (BBS, 2001).

In the present study based on field survey, observation and focus group discussions major livelihood groups are identified as farmer, fisher and wage labourer (Table 3). Farmer includes small, medium and large farmers. The present study finds that in study villages majority of farmers belongs to small farmer category. Likewise, fisher group includes fishermen and fish fry collector who usually catch fish in rivers, cannels and sea. Wage labourer group includes agricultural and non-agricultural labours, house keeper and/or maidservants. Profile of these livelihood groups in the study villages are presented in Table 3.

Table 3. Major livelihood groups in study villages.

\begin{tabular}{|l|c|c|c|c|c|c|c|c|}
\hline \multirow{3}{*}{ Livelihood group } & \multicolumn{9}{|c|}{ Study villages } \\
\cline { 2 - 11 } & \multicolumn{2}{|c|}{ Inland } & \multicolumn{2}{|c|}{ Shoreline } & \multicolumn{2}{|c|}{ Island } & \multicolumn{2}{|c|}{ All } \\
\cline { 2 - 10 } & $\mathrm{N}$ & $\%$ & $\mathrm{~N}$ & $\%$ & $\mathrm{~N}$ & $\%$ & $\mathrm{~N}$ & $\%$ \\
\hline Farmer & 68 & 34.34 & 20 & 22.22 & 12 & 27.91 & 100 & 30.21 \\
\hline Fisher & 42 & 21.21 & 50 & 55.56 & 28 & 65.12 & 120 & 36.25 \\
\hline Wage Labourer & 88 & 44.44 & 20 & 22.22 & 3 & 6.98 & 111 & 33.53 \\
\hline Total & 198 & 100.00 & 90 & 100.00 & 43 & 100.00 & 331 & 100.00 \\
\hline
\end{tabular}

Source: Household Survey, 2009.

\section{Fishers}

Number of fisher household is approximately 2.65 million in coastal zone as a whole, which is eight percent of total rural farm households of Bangladesh (PDOICZMP, 2004b; p.11). In general it is 14 percent of total coastal rural households of Bangladesh. Fishers are extremely poor and about 70 percent of them fall into small farmers category. Fish fry collectors are the subcategory of fisher livelihood group. About half million people in coastal zone is fry collector. To a large extent fry collectors depend on shrimp sector, which contributes 41 percent of household income. The present study finds that fisher is the largest livelihood group with 
36.25 percent of households among the study villages. In the case of individual villages $65.12,55.56$ and 21.21 percent households in Island, Shoreline and Inland village respectively belongs to fisher livelihood group (Table 3). It reveals that number of fisher group is significantly higher in Island followed by Shoreline and Inland villages. On the other hand, in fisher group about 44 percent depends on fry collection for maintaining livelihoods. Fishermen usually catch fish all the year round, but there are seasonal variations in the availability of fishes in rivers and sea. The fishermen who go for deep-sea fishing usually catch all the year round. While small scale fishers usually catch fish from May to November. Mid of November to mid of April is lean period for them. During this time they usually engage in wage labouring, repairing boats and nets, and agricultural activities. Major risks identified by this group are cyclone, storm surge, dadon ${ }^{1}$, and mahajani $^{2}$ system of borrowing. In fisher group, fish fry collectors are most subsistence sub-group usually collect fish fry during mid-December to June. Majority of the fry collectors are younger women and children. Few fishermen those do not have own boat and net also engage in fry collection. In general, fry collectors usually earn $80-120$ BDT (1-1.5\$) per day, while amount of earning is lower for women. This fry collector group is mostly found in Island and Shoreline villages. In Island village, irrespective of male and female collect fish fry, while in Shoreline women's participation in fry collection is comparatively less. Major risks hinder livelihoods of poor fry collectors are cyclone, storm surge, dadon and mahajani system, poverty and child labour.

\section{Wage labourer}

Wage labourer refers to the livelihood group whose primary source of income is obtained from either working as an agricultural or non-agricultural labour. Like other parts of the country majority of the wage labourers are involved in agricultural activities. In coastal Bangladesh number of agricultural labour household is 1.81 million, which is 33.2 percent of total coastal households. Among the wage labourer 55 percent belongs to small farmer and 43 percent landless (BBS, 2001). The present study finds that one third of total households are wage labourer category. Number of wage labourer is higher in Inland (44.44 $\%)$ village than Shoreline (22.22 \%) and Island (6.98\%) (Table 4). Wage labour livelihood group is higher in Inland because of village's agricultural economy. Majority of the wage labourers are small farmer or landless. Natural capital of inland village offer very limited options for poor villagers apart from working as wage labour. Whereas, in Shoreline and Island village vast natural resources (open water bodies and forests) offers several choices for villagers, such as independent entrepreneurships for fishing either in small or large scale. Hence, number of wage labour is found in limited scale in Shoreline village and very limited scale in Island village. Wage labour usually work all the year round. However, there is variation in availability of works. Average per day earning is 120 to 150 BDT (1.5-2.0\$) for wage labour irrespective of village locations. November to February is the lean period for wage labour in coastal villages because of limited availability

\footnotetext{
${ }^{1}$ Dadon is an advance payment of money for delivering catch fish under stipulated terms.

${ }^{2}$ The term Mahajan is applied to people hereditarily engaged in money lending
} 
of work in agricultural field and non-availability of fishes in the rivers. Based on household survey and focus group discussion it is found that major risks hindering the livelihoods of wage labour are poor transportation network, poor wages, uncertainties in getting job every day and illness.

\section{Farmer}

Among the surveyed households farmers are the third largest groups with 30.21 percent of total households. In farmer group, 77.66 percent is small and 23.34 percent is large farmer. Earlier studies reveal that in past few decades many large and medium farmers have turned into small farmer category in coastal zone because of the fragmentation of land due to increasing population and pauperization. Hence, numbers of small farmer have increased and numbers of medium and large farmers have sharply decreased in coastal zone (PDO-ICZM, 2004b). The present study finds that farmer is the second largest livelihood group in Inland with 34.34 percent households, 22.22 percent in Shoreline and 27.91 percent in Island village (Table 3 ). It shows that Inland village is predominantly agro-based, and majority of the respondents are directly or indirectly depended on agriculture. On the other hand, in Island and Shoreline villages agriculture is not dominant like Inland village. Hence, proportion of farmer group is relatively less and in general, farming activity depends on available cultivable land, and cropping pattern depends on suitability of land for single, double or multiple uses. This study also finds that land of Island village is suitable for single cropping. In Shoreline village both single and double cropped land are found. While in Inland village most of the land is double cropped and few is triple cropped. In single cropped land farmer used to cultivate transplanted Aman during kharif season (April to November). Rest of the time of the year is lean period, usually engage in other types of income earning activities such as fishing, fish fry collection, and livestock rearing etc. Soil salinity, lack of irrigation facility, cyclone and induced surges are major risks for single crop farming. Time period of cropping of double cropped land is April to November and cropping pattern is Rabi-Fellow-T. Aman. January to March is lean period for them. Triple cropped lands follow the cropping pattern of Rabi-T. Aus- T. Aman. Time period of cropping is March to May (prekharif) for T-Aus, June to November (Kharif) for T. Aman and November to February (Rabi) for winter vegetables, pulses and other Rabi crops. Major risks for double cropping are scarcity of irrigation water, tidal surge and soil salinity. High soil salinity and lack of irrigation facility are the key reasons of single cropping in Island and Shoreline villages. In Inland village, though lands are triple cropped, but scarcity of irrigation facility and moderate soil salinity in winter season hinder Rabi crop cultivation. Based on field survey and focus group discussion, major risks and uncertainties of farming identified are cyclone, storm surge, flood, land mortgage and loan from mahajans.

Major livelihood adversity and crisis in the study villages

Almost every year coastal population experience damage of assets, crops, poultry, livestock, houses and livelihoods by cyclone, coastal flooding, tidal surge, coastal erosion and so on. Cyclone is most common form of hazard in coastal Bangladesh, and strike on an average every two to three years. Southern part of Bangladesh is 
surrounded by the Bay of Bengal, and any cyclone formed in the sea always is accompanied by storm surge and inundates entire coastal belts. Therefore, any surge strikes the land always causes huge impacts on coastal population's livelihoods. The cyclones cause devastation of agricultural production, damage houses and other infrastructure and resulted in deaths. Coastal erosion is a key problem, as most of the lands are active delta, which are recently inhabited and cultivated, worn out due to abnormal water movement and coastal flooding.

Table 4. Major adversity and crisis in a year in the study villages (Multiple responses).

\begin{tabular}{|l|c|c|c|c|c|c|c|c|}
\hline \multirow{3}{*}{ Adversity and crisis } & \multicolumn{7}{|c|}{ Study villages } \\
\cline { 2 - 11 } & \multicolumn{2}{|c|}{ Inland } & \multicolumn{2}{c|}{ Shoreline } & \multicolumn{2}{c|}{ Island } & \multicolumn{2}{c|}{ All } \\
\cline { 2 - 10 } & $\mathrm{N}$ & $\%$ & $\mathrm{~N}$ & $\%$ & $\mathrm{~N}$ & $\%$ & $\mathrm{~N}$ & $\%$ \\
\hline Cyclone & 198 & 36.1 & 90 & 30.5 & 43 & 27.2 & 331 & 33.0 \\
\hline Storm surge & 156 & 28.4 & 90 & 30.5 & 43 & 27.2 & 289 & 28.8 \\
\hline Salinity intrusion & 0 & 0.0 & 5 & 1.7 & 42 & 26.6 & 47 & 4.7 \\
\hline Loss of trees & 85 & 15.5 & 37 & 12.5 & 15 & 9.5 & 137 & 13.7 \\
\hline $\begin{array}{l}\text { Loss of agricultural } \\
\text { productions }\end{array}$ & 55 & 10.0 & 23 & 7.8 & 4 & 2.5 & 82 & 8.2 \\
\hline Loss of fish production & 26 & 4.7 & 28 & 9.5 & 6 & 3.8 & 60 & 6.0 \\
\hline Illness & 14 & 2.6 & 22 & 7.5 & 5 & 3.2 & 41 & 4.1 \\
\hline Flood & 4 & 0.7 & 0 & 0.0 & 0 & 0.0 & 4 & 0.4 \\
\hline Coastal erosion & 9 & 1.6 & 0 & 0.0 & 0 & 0.0 & 9 & 0.9 \\
\hline $\begin{array}{l}\text { Sand deposition on } \\
\text { agricultural land }\end{array}$ & 2 & 0.4 & 0 & 0.0 & 0 & 0.0 & 2 & 0.2 \\
\hline \begin{tabular}{l} 
Total \\
\hline
\end{tabular} & 549 & 0 & 295 & 100.0 & 158 & 0 & 2 & 100.0 \\
\hline
\end{tabular}

Source: Household Survey, 2009.

The present study finds that 33 percent of the respondent had identified cyclone as a major impediment in all three villages. Secondly, storm surge was identified as a major hazard by 30.5 and 27.2 percent of respondents in Shoreline and Island villages, and 28.4 percent respondents in Inland village (Table 4). It is because while cyclone strikes always accompanied by storm surge in Shoreline and Island villages, whereas due to the low strength of cyclone, Inland village remain relatively safer. Salinity intrusion was identified as a major problem by the respondents of Island village. During dry season soil salinity emerges as a severe problem for farmer, which further aggravate due to shrimp cultivation. In addition, some other problems such as loss of fruit trees, agricultural productions, fish productions and illness of inhabitants are also identified by the villagers of all three locations. Moreover, some other adversities such as flood, coastal erosion and sand deposition on agricultural land were identified by few respondents. Illness of inhabitants was identified by the respondent irrespective of village location, while coastal flooding and sand deposition on agricultural land is identified as problems in Inland village. 
Income diversification and livelihood strategies to combat adversities

According to the filed survey, 2009, farmer in all the study villages are not only engaged in agriculture but also simultaneously engaged in fishing, animal husbandry, selling of crops, coconut, betel nut and dairy products etc. Due to the subsistence nature of income earning at household level majority of small and subsistence fisher involves in wage labouring in addition to their primary occupation. Field survey and key informant interviews unveils that such process of income diversification of rural households has further been taken place rapidly due to the changes in demographic characteristics (increasing population and migration) and cultural transform in rural societies such as occupational diversity, women's participation in economic activities etc. Such changes are exemplified by people's increasing involvement in various income earning activities, involvement in other's occupational domain (such as farmer to seasonally fishing) and women's increasing engagement in income earning activities apart from house work (such as food or cash for work) which changes traditional livelihood pattern of coastal areas (PDO-ICZM, 2004a).

Table 5. Combination of livelihood activities at household level in study villages.

\begin{tabular}{|l|l|}
\hline \multicolumn{1}{|c|}{ Male } & \multicolumn{1}{c|}{ Female } \\
\hline Agriculture, farm labour; & Home gardening, poultry and cattle raring \\
\hline Agriculture, petty business; & $\begin{array}{l}\text { Partial involvement in agriculture, poultry } \\
\text { and cattle rearing, aquaculture; }\end{array}$ \\
\hline Farm labour, rickshaw/van pulling; & Paddy harvesting and husking, net making; \\
\hline $\begin{array}{l}\text { Non-farm labour, fishing, } \\
\text { rickshaw/van pulling; }\end{array}$ & $\begin{array}{l}\text { Poultry and goat rearing, collecting cow dung } \\
\text { for fuel; }\end{array}$ \\
\hline $\begin{array}{l}\text { Agriculture, share cropping, paddy } \\
\text { husking; }\end{array}$ & $\begin{array}{l}\text { Paddy harvesting and husking, puffed rice } \\
\text { (muri) preparing and selling, duck keeping, } \\
\text { egg selling; }\end{array}$ \\
\hline $\begin{array}{l}\text { Agriculture, cattle grazing, pond } \\
\text { aquaculture, fishing }\end{array}$ & $\begin{array}{l}\text { Wage labour, earthwork (food for work/cash } \\
\text { for work), fish fry collection }\end{array}$ \\
\hline $\begin{array}{l}\text { Shrimp and other pond aquaculture, } \\
\text { farming, day labour; }\end{array}$ & $\begin{array}{l}\text { Fish fry collection, wage labour } \\
\text { (maidservant), net repairing }\end{array}$ \\
\hline $\begin{array}{l}\text { Shrimp fry collection wage labour, } \\
\text { fishing net preparing and repairing, }\end{array}$ & $\begin{array}{l}\text { Wage labour, maidservant, cow-dung and } \\
\text { fuel wood collection; }\end{array}$ \\
\hline $\begin{array}{l}\text { Fishing, fish trading, agriculture, } \\
\text { aquaculture; }\end{array}$ & $\begin{array}{l}\text { Wage labour, paddy husking, Puffed rice } \\
\text { (muri) preparing, earth work, kantha } \\
\text { making; }\end{array}$ \\
\hline $\begin{array}{l}\text { Pond aquaculture, business, agriculture } \\
\text { and share cropping }\end{array}$ & $\begin{array}{l}\text { Fish fry collection, fishing, net making and } \\
\text { repairing. }\end{array}$ \\
\hline
\end{tabular}

Source: Household Survey, Focus Group Discussion, 2009.

Various factors encouraged households to involve in multiple occupations to optimize income earnings to reduce risks, although preferences for such multiple occupations are limited due to lack of opportunities. In fact, most of the coastal households are heavily dependent on natural resources for earning livelihoods.

\footnotetext{
${ }^{3}$ Kantha is a type of embroidery popular in Bangladesh. Women typically use old saris and cloths and layer them together and stitch to make like a light blanket.
} 
Hence occupations are seasonal in nature. Similarly, scope to switch from one occupation to another is limited because such switching of occupation needs extra skills apart from main occupation. Though, there is constrains in switching of occupations, the present study finds that household with single income earning activity is rare in all surveyed villages. Many of households depend on multiple income earning activities. Such as fishermen remain unemployed about two third of time in a year. Therefore, for survival they engage in wage labouring or working in agricultural field as haired labour. Likewise, women are also increasingly involving themselves in different income earning activities apart from household everyday tasks. Different combination of activities had performed by men and women in three study locations are presented in Table 5.

Livelihood activities are influenced by various external entities; for example livelihood capitals, shocks and adversities, and various institutional factors. Considering the opportunities of various assets and constrains of multiple adversities and crises a household make livelihood choices. However, such choice is to maximize livelihood opportunities and minimize risks. Livelihood assets play a vital role in the process of livelihood options and choices of livelihood activities by household members. A household may change one livelihood asset to other to maximize the livelihood outcomes. Such exchange of livelihood assets depends on the livelihood options from which a household can make maximum gain, which usually reflects in livelihood activities. Similarly, a household is usually allied with various local resources in the form of access and entitlement. Such access to resources is also one of the determining factors of livelihood choices. In addition to the livelihood assets and recourses, overall institutional setup is another form of determining factors of livelihood choices. Such institutions can be the local formal or informal rules, traditional beliefs, norms and attitudes etc., and as well as state intuitions. In this livelihood process various exogenous forces creates vulnerability of a household to multiple stressors. The present study has identified cyclone and storm surge as important factors of vulnerability of coastal households. These factors might affect a household either directly or indirectly. Household's level of resilience or sensitivity to such factors reflects ability to cope with these vulnerabilities. The present study finds that to combat such vulnerabilities to natural hazards household usually adopts a range of coping strategies with a sequence of pre-during and post cyclone (Paul \& Routray, 2010b). However, based on the level of coping capacity a household makes strategic livelihood choices.

The total process of coastal livelihood strategies could be better understood by the schematic diagram presented in Figure 4. The upper part of the diagram presents access of households to various livelihood capitals such as, open water, financial sources, rural formal institutions, physical resources and various groups at village level. Apart from these, each household have their own asset portfolios, which offer various livelihood choices. From a range of livelihood options a household usually undertakes a suitable income earning activity or a combination of suitable activities. Moreover, various factors such as natural hazards, illness and seasonality etc. create vulnerability of a household. In response to such 
vulnerabilities a household undertakes ranges of suitable coping measures. Finally, based on the income and budget a household carries out consumption and expenditure strategies, which unveils its level of livelihood security (Figure 4).

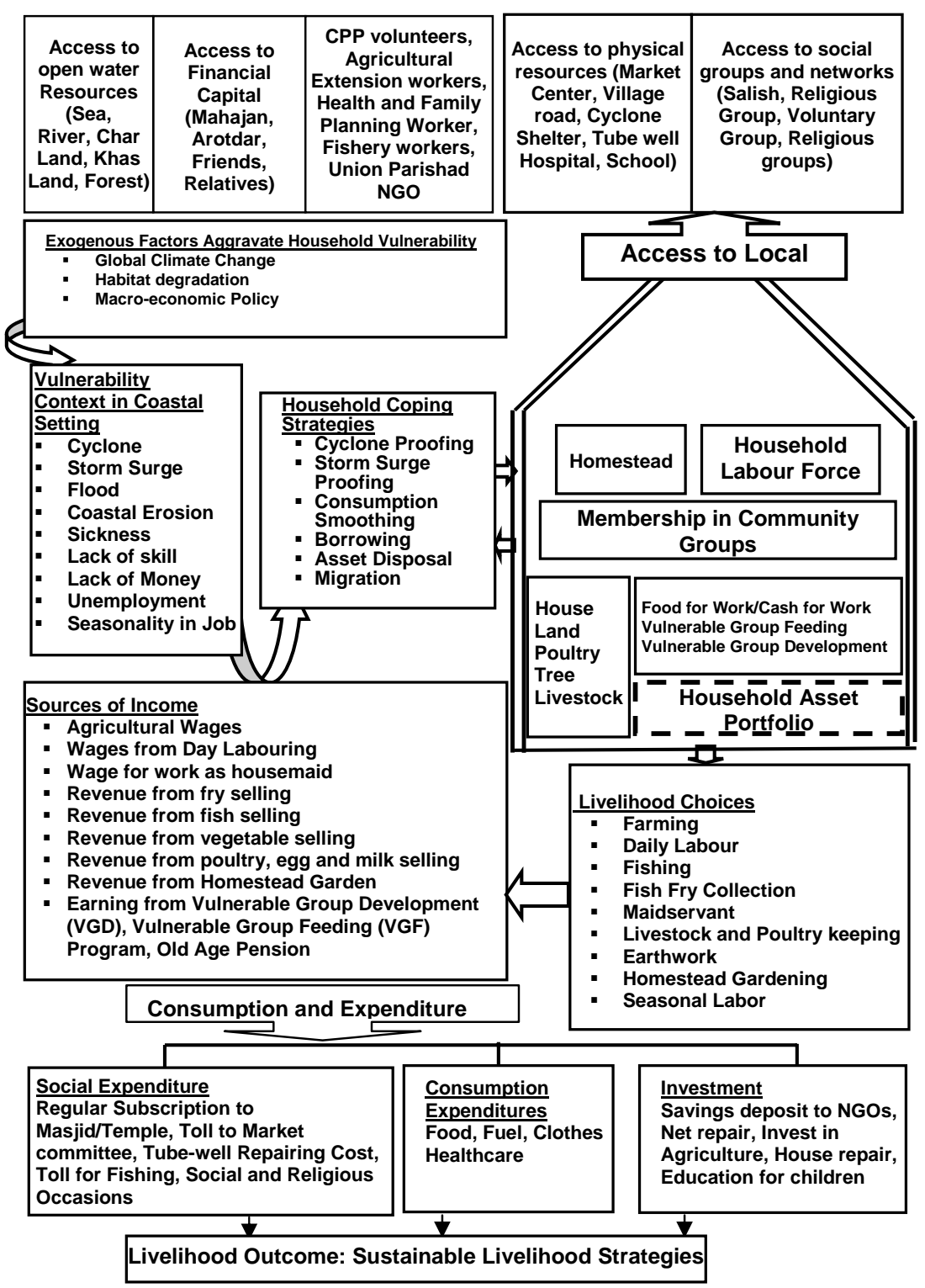

Figure 4. Livelihoods of coastal rural households.

(Based on Household Survey, Focus Group Discussion, and Key Informant Interviews, 2009) 
The present study identifies three major livelihood groups such as farmer, fisher and wage labourer. Distribution of livelihood capitals among the three villages reveals significant differences. Island village lacks behind than the Inland and Shoreline villages in terms of livelihood capitals, though natural capital for Island is relatively higher. The scarcity of capitals hinders the proper utilization of the potentials of natural capital of Islanders. Social capital for Island is significantly lower than other two villages, which unveils relatively lesser social coherence of Islanders which is most important to survive in disaster situation. As most of the inhabitants in Island village are the immigrants from inland locations, thus social bonding is relatively less. Likewise, among the livelihood groups, wage labourers are having less livelihood capitals than farmer and fishermen. Majority of the households irrespective of their village locations have identified cyclone as a major adversity which significantly destroys their livelihoods. Most of the coastal households are not dependent only on single income earning activities. Households in study villages diversify income sources wherever possible and most importantly while they face the crisis. Such diversification of income earning activities unveils the transformation process of traditional typical coastal livelihoods. In general livelihoods of Islanders and Shoreline villagers are more vulnerable to cyclone and storm surge. While as a livelihood group wage labourer and fish fry collectors are most vulnerable to any hazard events. Based on the findings, this study reveals that cyclone survivors of the island village, wage labourer and fish fry collectors are more vulnerable to cyclone due to the lack of livelihood capitals than other two villages and livelihood groups considered in the present study. Therefore, the present study advocates for targeting vulnerable locations for example the island village, and vulnerable livelihood groups like wage labourer and fish fry collector for disaster risk reduction that may more adequately address post-cyclone livelihood insecurity in coastal Bangladesh. Besides, creation of post-cyclone income earning activities such as 'cash for work' and 'food for work' for vulnerable groups and locations could be fruitful to reduce post-cyclone hardships for shorter periods. Apart from such activities post-cyclone livelihood rebuilding such as credit support for boats, nets, livestock and agriculture could provide benefit for longer periods. Moreover, emphasis should be given on coordinated disaster risk reduction and re-building of livelihoods such as assistance for producing food rather than providing food. In other words, supports should be expanded and continued for income generating activities for the rural poor in disaster prone areas which could reduce the prevalence of post disaster livelihood insecurity for longer period of time.

\section{References}

Ali, A. 1980. Storm surges in the bay of Bengal and their numerical modelling. SARC Report No. 125/80. Atomic Energy Commission, Dhaka.

Ali, A. 1996. Vulnerability of Bangladesh to climate change and sea level rise through tropical cyclones and storm surges. Water, Air, \& Soil Pollution, 92(1-2):171-179.

Ali, A. 1999. Climate change impacts and adaptation assessment in Bangladesh. Climate Research, 12(2-3): 109-116.

BBS (Bangladesh Bureau of Statistics). 2001. Preliminary report of household income and expenditure survey 2000. Ministry of Planning, Dhaka. 
Blaikie, P., Cannon, T., Davis, I. \& Wisner, B. 1994. At risk: natural hazards, people's vulnerability and disasters. Routledge, London.

Carney, D. 1998. Implementing the sustainable rural livelihoods approach. In: Carney, D. (ed): Sustainable rural livelihoods-what contribution can we make? Paper presented at the Department for International Development's Natural Resources Advisers' Conference, July 1998. Department for International Development, London: 3-23.

Carney, D., Drinkinwater, M., Rusinow, T., Neefjs, K., Wanmali, S. \& Singh, N. 1999. Livelihoods approaches compared: a brief comparison of livelihoods approaches of the UK Department of International Development, CARE, Oxfam and United Nations Development Program. Department for International Development, London.

Choudhury, A.M. 1989. Forecasting and warning system of disaster. A SPARRSO Report. Bangladesh Space Research and Remote Sensing Organization, Dhaka.

Choudhury, W.A., Quraishi, F.A. \& Haque, Z. 2006. Mental health and psychological aspects of disaster preparedness in Bangladesh. International Review of Psychiatry, 18(6): 529-535.

Chowdhury, M.H.K. 1995. Critical assessment of tropical cyclones in the Bay of Bengal: Bangladesh perspective. Paper presented at the workshop on Global Change and Tropical Cyclones. 18-21 December, Dhaka.

DFID, 1999. Sustainable livelihoods guidance sheets, Section 2, The livelihoods framework. Department for International Development, London.

Dube, S.K., Rao, A.D., Sinha P.C., Murthy T.S. \& Bahulayan N. 1997. Storm surge in the Bay of Bengal and Arabian Sea: the problem and its prediction. Mausam, 48: 283-304.

Elahi, K.M. 1991. Impacts of riverbank erosion and flood in Bangladesh: an introduction. In: Elahi, K.M., Ahmed, K.S. \& Mafizuddin, M. (eds) : Riverbank Erosion, Flood and Population Displacement in Bangladesh. Riverbank Erosion Impact Study (REIS), Jahangirnagar University, Dhaka.

GoB (Government of Bangladesh), 2008. Summary of cyclone situation: emergency storm Sidr, retrieved from http://www.mofdm.gov.bd/sidr\%20damage.htm, viewed in August, 2008.

GoB (Government of Bangladesh), 2008a. Cyclone Sidr in Bangladesh: damage, loss and needs assessment for disaster recovery and reconstruction. Government of Bangladesh, Dhaka.

GoB (Government of Bangladesh), 2008b. Super Cyclone Sidr 2007: impacts and strategies for interventions. Government of Bangladesh, Dhaka.

Haider, R., Rahman A.A., \& Huq S. 1991. Cyclone '91, an environmental and perceptional study. Bangladesh Centre for Advanced Studies, Dhaka.

Haque, C.E. 1995. Climatic hazards warning process in Bangladesh: experience of, and lessons from, the 1991 April cyclone. Environmental Management, 19(5):719-734.

Haque, C.E. 1997. Atmospheric hazards preparedness in Bangladesh: A study of warning, adjustments and recovery from the April 1991 cyclone. Natural Hazards, 16(2-3): 181-202.

Islam, A.K.M.S., Bala, S.K., Hussain, M.A., Hossain, M.A. \& Rahman, M. 2011. Performance of coastal structures during cyclone Sidr. Nat. Hazards Rev., 12(2):111-116.

Mallick, B., Witte, S.M., Sarkar, R., Mahboob, A.S. \& Vogt, J. 2009. Local adaptation strategies of a coastal community during cyclone Sidr and their vulnerability analysis for sustainable disaster mitigation planning in Bangladesh. Journal of Bangladesh Institute of Planners, 2: 158-168. 
Mooley, D.A. 1980. Severe cyclonic storms in the Bay of Bengal, 1877-1977. Monthly Weather Review, 108(10): 1647-1655.

Moser, C, Gauhurts, M. \& Gonhan, H. 1994. Urban poverty research source book: sub-city level research. World Bank, Washington DC.

Murty, T.S. \& El-Sabh, M. 1992. Mitigating the effects of storm surges generated by tropical cyclones - a proposal. Natural Hazards, 6(3): 251-273.

Murty, T.S. \& Neralla, V. R. 1992. On the recurvature of tropical cyclones and the storm surge problem in Bangladesh. Natural Hazards, 6(3): 275-279.

Paul S.K. \& Routray J.K. 2010a. Flood proneness and coping strategies: the experiences of two villages in Bangladesh. Disasters, 34(2): 489-508.

Paul S.K and Routray J.K. 2010b. Household response to cyclone and induced surge in coastal Bangladesh: coping strategies and explanatory variables. Natural Hazards. 57(2): 477-499.

Paul, S.K., \& Routray, J.K. 2012. An analysis of the causes of non-responses to cyclone warnings and the use of indigenous knowledge for cyclone forecasting in Bangladesh. In: Filho, W.L. (ed). Climate change and disaster risk management, Springer, Berlin. 2012: 15-39.

Paul, B.K. \& Dutt, S. 2010. Hazard warnings and responses to evacuation orders: the case of Bangladesh's cyclone Sidr. The Geographical Review, 100(3): 336-355.

Paul, B.K. 2009. Why relatively fewer people died? The case of Bangladesh's cyclone Sidr. Natural Hazards, 50(2): 289-304.

Paul, B.K. 2010. Human injuries caused by Bangladesh's cyclone Sidr: an empirical study. Natural Hazards, 54(2): 483-495.

Paul, S.K. 2010. Prevalence of nutritional insecurity in the central coast of Bangladesh: evidences from cyclone Sidr. The Journal of Geo-Environment, 10:22-35.

Paul, S.K. 2012. Vulnerability to tropical cyclone in the southern Bangladesh: impacts and determinants. Oriental Geographer, 53(1-2): 19-40.

Paul S.K. 2014. Determinants of evacuation response to cyclone warning in coastal areas of Bangladesh: A Comparative Study. Oriental Geographer, 55(1-2): 57-84.

Paul, B.K., Rahman, M.K., \& Rakshit, B.C. 2011. Post-cyclone Sidr illness patterns in coastal Bangladesh: an empirical study. Natural Hazards, 56(3): 841-852.

Paul, S.K., Paul, B.K., \& Routray, J.K. 2012. Post-cyclone Sidr nutritional status of women and children in coastal Bangladesh: an empirical study. Natural Hazards, 64(1): 19-36.

PDO-ICZMP (Program Development Office for Integrated Coastal Zone Management Plan), 2004a. Where land meets the sea: a profile of the coastal zone of Bangladesh. University Press Limited, Dhaka: 317.

PDO-ICZMP (Program Development Office for Integrated Coastal Zone Management Plan), 2004b. Living in the coast-people and livelihoods. Program Development Office for Integrated Coastal Zone Management Plan, Water Resources Planning Organization, Ministry of Water Resources, Government of the People's Republic of Bangladesh, Dhaka: 1-11.

Permanasari, A. E., Rambli, D.R.A. \& Dominic, P.D.D. 2010. Forecasting method selection using ANOVA and Duncan multiple range tests on time series dataset. In: Mahmood, A.K. et al., (eds). Proceedings of the International Symposium on Information Technology 2010, ITSim, Vol. 2: Engineering Technology. Institute of Electrical and Electronics Engineers (IEEE), Kuala Lumpur, June 2010:941-945. doi: 0.1109/ITSIM.2010.5561535. Retrieved from http://ieeexplore.ieee.org/stamp/ stamp.jsp?tp=\&arnumber $=5561535 \&$ isnumber $=5561380$. 
Sanderson, D. 2000. Cities, disaster and livelihood. Environment and Urbanization, 12(2): 93-102.

Shivakoti, G. \& Shrestha, S. 2005. Analysis of livelihood asset pentagon to assess the performance of irrigation systems (Part 1-analytical framework). Water International, 30(3): 356-362.

Uddin, M.E. 2012. Household food security status of marginal farmers in selected storm surge prone coastal area of Bangladesh. The Agriculturists, 10(1): 98-103.

UN. 2007. Cyclone Sidr United Nations rapid initial assessment report with a focus on 9 worst affected districts. Final report. Retrieved from: http://www.lcgbangladesh.org/ derweb/cyclone/cyclone_assessment/2007-11-22_UN\%20Rapid\%20Assessment\%20 Report_Bangladesh.pdf on 24 November 2007.

Yamane, T. 1967. Statistics: an introductory analysis. $2^{\text {nd }}$ ed. Harper and Row, New York. 